\title{
Why use experiments in EU Studies?
}

Nielsen, Julie Hassing

Published in:

Comparative European Politics

DOI:

10.1057/cep.2014.37

Publication date:

2014

Citation for published version (APA):

Nielsen, J. H. (2014). Why use experiments in EU Studies? Comparative European Politics, Early online view. https://doi.org/10.1057/cep.2014.37 


\title{
Review Article
}

\section{Why use experiments in EU studies?}

\author{
Julie Hassing Nielsen \\ Department of Political Science, University of Copenhagen, Øster Farimagsgade 5. Opgang E 1353. \\ Kobenhavn $\mathrm{K}$. \\ E-mail: jhn@ifs.ku.dk
}

\begin{abstract}
The past decades have witnessed an explosion in the use of experiments. Though experiments have been increasingly applicd, their recognition as useful methodological tools to investigate EU-related research questions has lagged behind the rest of the political science community. This article does two things. First, by summarising the use of experiments in EU research, it provides an overview of the evolution of the use of experiments within EU studies. This includes a content exploration of the pionecring sub-areas within EU studies where experimentation is frequently used. Particular focus is paid on clection, framing and delibcration studies. Second, the article argues for the promising potentials experimentation provides for EU studies, overcoming problems of causal estimation as well as endogeneity concerns. The article concludes by addressing some of the critiques often made against experimentation, arguing for a renewed view on validity.

Comparative European Politics advance online publication. 15 September 2014; doi:10.1057/cep.2014.37
\end{abstract}

Keywords: experiments; EU studies; political psychology; election studies; deliberation; framing

\section{Introduction}

Experimentation is the 'new black' in political science methodology. And its rise to prominence is probably best illustrated by the field of political science receiving its first Nobel prize for Ostrom's pioneering experimental work on common pool resources (for example, Ostrom et al, 1992). As documented elsewhere, the use of experimental methods in political science exploded in recent years while, simultaneously, the work done by experimentalists received much more frequent citations (for example, McDermott, 2002; Druckman et al, 2006; Morton and Williams, 2010; Druckman et al, 2011).

But what is the status of the use of experiments in EU studies? And how can this method help us address new questions and overcome weaknesses in currently used research methods? This article addresses these questions. Though experimental

(3) 2014 Macmillan Publishers Lid. 1472-4790 Comparative European Polities 1-19 www.palgrave-joumals.com/cep/ 
importance of the behavioural turn in political science (Ostrom, 1998). So what had happened in between the two speeches, when experiments went from being an ill-regarded methodology widely perceived as unsuitable for political science to a rather prosperous methodology?

One of the answers lies in the evolution of the research questions the academic community engages with. In recent years, interest has moved beyond the macro level broad socio-demographic phenomenon to include micro level behavioural and psychological political aspects. These aspects include increased attention to the role of cognition (for example, Lay and Redlawsk, 2001), explorations of the role of emotions (for examle, Marcus, 2003; Keltner and Lemer. 2010), or the importance of media framing on political attitudes (for example. Chong and Druckman, 2007). Yet, the revival of experimentation, though happening simultaneously with increased interest in political psychology, is not dependent on the scientific interest in psychology. Rather, experimentation is as a new tool in the more general political science toolbox, addressing a variety of research questions as, for example, the content of the (2011) Cambridge Handbook of Experimental Political Science witnesses.

Another answer lies in the fact that political science has opened up for new understandings of causal inference and scientific validity. Until recently, experiments were ill-regarded because they do not rely on the representative large-n sample normally associated with inference and validity. Rather experiments draw inference from treatment randomisation, while the robustness of the experimental design is judged through the concepts of construct validity and mundane, psychological and experimental realism (for example, Druckman and Kam, 2011). I discuss these aspects later. Yet the opening of a broader understanding of what constitutes robust and valid research secured experiments a more permanent place in the political science toolbox.

So why use experiments to explore political questions when sophisticated statistical methods like, for example, instrument variable estimation is available? Three aspects make experiments superior. First, the researcher's active involvement in the data generating process enables a very precise and narrow identification strategy. Consequently, if the design is also theoretically well-grounded, experiments probably provide the best possibility for solid construct validity available. In contrast, the above-mentioned research technique use already generated observational data. Here, the researcher lacks the opportunity to intervene in the data generating process, and thus lacks the possibility of separating endogenously embedded variables. As a result, these sophisticated estimation techniques offer less solid construct validity because construct validity is accounted for post hoc.

Second, experiments overcome endogeneity problems. Though endogeneity problems are endemic in political science (for example, Hug, 2003), certain research areas and questions are more challenged by endogeneity concerns than others. Particularly, these include psychological questions, where, for example, emotions or cognition often are highly endogenous to either the cause or the outcome one wishes to explore. Experiments overcome these concerns through designs, which are capable to identify

O 2014 Macmillan Publishers Ltd. 1472-4790 Comparative European Politics 1-19 
encompasses an experiment which overlaps these categories, it is only included in what is understood to be its main category. Deliberative polls are registered as lab experiments though I later argue for their potentials as field experiments. A total of 25 of the main EU research joumals are included. These journals are found using the official academic 'Autoritetsliste' from the Danish Ministry of Science, which encompasses a yearly ranking of all intemational political science peer-reviewed joumals. ${ }^{2}$ Hence interdisciplinary joumals or experimental work on EU-related issues outside political science journals are not included. Additionally, journals featuring only national-oriented material are not included. However, Acta Politica and Scandinavian Political Studies (that is, two regional journals) are included as they have a scope beyond national politics, they are widely cited beyond the national sphere, and they orient themselves towards the EU community by publishing exclusively in English and frequently addressing EU topics. Though EU studies are multilingual by definition, English remains the predominant language in which studies are conducted and disseminated (for example, Coakley and Doyle, 1996). Hence the figures below include only English articles.

The search for articles was initially limited to the period of 1990-2013, because previous explorations showed a dramatic increase in the use of experimentation from 1990s (for example, Druckman et al, 2006: Morton and Williarns, 2010). As I am interested in exploring the extent to which a similar trend is found in EU studies, the 1990s appear a good starting point. Importantly, no articles on experiments were found prior to 2000 in the journals included here. Consequently, Figures 1 and 2 only feature the period between 2000 and 2013, including articles released for early online view.

Figure 1 shows the EU articles relying on experimental data from 2000 to 2013. On the basis of the more general studies done on the use of experiments, we would expect a rapid increase in this period, which is indeed what we find. From 2000 to 2002, Figure 1 reports no published articles on experiments within EU studies. This figure changes at the end of the decade where we find a doubling of the occurrence of experimental articles from 2009 to 2011 (from 2 to 4). From 2010 to 2011 the numbers of articles using experiments again almost double from 4 to 7 in 2011 . The decreasing trend observed from 2012 to 2013 (from 6 to 3 articles) can most Jikely be ascribed to the fact that data was only collected to include early online view or published articles up until spring 2013 where data was collected. Importantly, the figures below witness a somewhat belated experimental endorsement in EU studies compared with the general trend within political science, where experiments had already risen to prominence in the 1990 s (for example, Druckman et al, 2006).

\section{What Kind of Experiments?}

The increase in experimental articles follows the general trend of increased attention to the study of causality in EU studies (for example, Haverland. 2006; Exadaktylos

O 2014 Macriillan Publishers Ldd. 1472-4790 Comparative European Politics I-19 
real-life environment. Thus the greatest strength of lab experiments is simultaneously also their greatest weakness as the ability to control intervening and confounding factors in the lab also induces artificiality to the experimental findings.

Survey experiments comprise treatments in regular survey questionnaires. Often they involve different news frames or other kinds of information manipulation on political topics (for example. Sniderman, 2011). Survey experiments gained increasing popularity as user-friendly software became more accessible. Also, survey experiments are beneficial as they more easily include a large-n representative sample of subjects while still being able to live up to the treatment randomisation criteria. Thus they (often) conveniently overcome the criticism about the lack of external validity of experiments. Yet one critique is that treatments are often not reiterated in ways subjects experience in real life, which is an aspect that might influence the observed treatment effect vis-à-vis, for example, natural experiments (for example, Gaines et al, 2006; Barabas and Jerit, 2010).

Field experiments are situated in the subjects' natural environment. This way field experiments compromise the ability to control confounding factors as well as observable or unobservable variables that might intervene and influence the treatment effect (for example, Gerber, 2011). Yet field experiments are attractive in situations where the environment is expected to play a role for the causal relationship in question: for example, if one wishes to test the effect of canvassing vis-à-vis other ways of increasing voter turnout in national elections (for example, Gerber and Green, 2000). These topics are hard to manipulate in labs without compromising the crucial context of 'being at subjects' homes'. Thus field experiments best fit these kind of research questions, which are critical to democratic research also in EU Studies.

In natural experiments treatment randomisation occurs haphazardly. As the mechanisms assigning treatments are naturally occurring, treatment randomisation is labelled 'as if random' (for example, Dunning, 2008). However, as treatment and control groups are constructed post hoc, the randomisation technique must be more convincingly accounted for vis-à-vis other experimental designs (for example, Sekhon and Titiunik, 2012). These post-hoc assumptions are manifested by strong insights into the details of the explored cases so the researcher ensures that no selfselection mechanisms render the design to be spurious. Thus natural experiments depart from regular comparative studies by the treatment randomisation assumption, allowing the researcher to make causal claims on the basis of a natural occurring event instead of mere comparison or correlation. Yet, as with field experiments, natural experiments are simultaneously challenged and blessed by taking place in subjects' natural environment.

The four categories of experimental designs are not equally applied in EU research. Figure 2 summarises the frequency of the use of each of the four categories. As seen, survey and lab experiments are significantly more popular than field and natural experiments. Where 13 of the articles encompassing experiments in the period between 2000 and 2013 used a survey design, and nine articles used

O 2014 Macmillan Publishers Ltd. 1472-4790 Comparative European Politios 1-19 
Why use experiments in EU studies?

\section{Election studies}

Along with the discussion about EU democratisation (for example, Moravcsik, 2002; Foellesdal and Hix, 2006) comes the study of voter behaviour and turnout in European Parliament (EP) elections as well as in national EU referendums. The poor voter turnout in EP elections, as well the rejection of further integration in referendums, enhanced attention on the EU democratic malaise and euro-scepticism (for example, Franklin et al, 1995; Hooghe and Marks, 2007; McLaren, 2007; Hobolt, 2009; Usherwood and Startin, 2013). Experiments within election studies and voter behaviour essentially address these questions, though variation exists inside this particular focus.

Examining the micro-foundations for voter behaviour in EP elections, Hobolt and Wittrock (2011) design a lab experiment to explore the second-order election hypothesis, that is, that Europeans treat EP elections as of secondary importance vis-à-vis national elections (Reif and Schmitt, 1980). Hobolt and Wittrock use a rare mixed sample consisting of students and non-students. By manipulating types of information, the sender of the information and the placement of political parties, they find that EP election voter choice is primarily based on national political contestation, though information level also plays a role (Hobolt and Wittrock, 2011). Similarly. Maier et al (2012) test the effect of party communication on EU support. Relying on party communication from a cross-country survey experiment during the 2009-EP election, they explore the effect of positive and negative EU economic and identity framing. They conclude that only negative economic framing is directly measurable on EU support (Maier et al, 2012).

Turming to national EU referendums, Jupille and Leblang (2007) adapt the Danish (2000) and Swedish (2003) referendums on the Euro adoption as a natural experiment. Both countries are union members, and both countries remain outside the EMU's third phase. Denmark, however, pursues a fixed euro exchange rate, contrasting Sweden with a floating euro exchange rate. Assuming the differences in exchange rate policies are provided 'as if randomly', Jupille and Leblang explore the extent to which these policies influence economic and/or political community speculations, and play a role for referendum outcomes. Where political community framing effects are strong in both cases, economic calculations have greater impact in Sweden (Jupille and Leblang, 2007).

Outside the EP election and referendum contexts, Brader and Tucker (2012) conduct a cross-national survey experiment in three Member States, exploring whether party cues affect policy opinion. They find that party cues influence political preferences in all countries, concluding that the link between party cues and policy opinion exists in a broader political context (Brader and Tucker, 2012). With a similar design, Brader et al (2012) explore whether political partisans expose more loyalty towards their party if the party is old and well-established vis-à-vis a new and yet-to-be-established party. Their findings confirm that partisans more strongly follow their party's lead in old established parties (Brader et al, 2012).

O 2014 Macmillan Publishers Lid. 1472-4790 Comparative European Politios I-19 
investigate the framing effects of Serbia's EU candidacy. Using a survey experiment, they argue that news framing about Serbian candidacy impact opinions about the country's entrance. However, this effect is moderated by knowledge (Lecheler and Vreese, 2010).

Framing effects on more specific EU policy areas are also studied in experiments. De Vreese and Kandyla (2009) test the extent to which framing difference on EU's Common Foreign and Security Policy (CFSP) affects opinions about the issue. Framing the CFSP as either a national risk or an opportunity, they find framing has a significant impact on attitudes towards it. In particular, subjects fearing globalisation accept the risk frame more willingly (Vreese and Kandyla, 2009). Exploring the impact of framing on attitudes towards the Europeanisation of welfare, Kumlin (2011) confirms in a survey framing experiment the main 'blame-avoidance' hypothesis, meaning that subjects receiving a positive EU frame do not only become EU positive: they also become increasingly negative towards domestic politics (Kumlin, 2011). He generates the results by randomly assigning politically biased background information about welfare.

Also the role of framing on the creation of an EU identity is explored. Using a cross-country panel survey experiment, Bruter (2009) shows that it is not only exposure to good or bad EU news that matters for people's EU identity. The good and, in particular, the bad EU coverage accumulates over time. Consistent framing here based on a three-wave six-country panel experiment where subjects are continuously exposed to particular news frame - thus severely impacts long-term identity-formation (Bruter, 2009). And, lastly, in a cross-national survey experiment, Abbamo and Zapryanova (2013) investigate if elite framing on the EU's democratic deficit or the EU as a cultural threat cultivates democratic support. They conclude that both frames decrease EU support. Notwithstanding, the democratic deficit frame enhances the support for democratic values (Abbamo and Zapryanova, 2013).

In EU research, framing studies are tied to survey experiments to ensure the desired large-n representative sample, while maintaining the experimental ability to explore causality and ensure experimental realism as subjects receive treatment in their own environment. Yet, these findings would benefit from the inclusion of more 'real life' contexts where subjects receive political frames and messages. Hence, as with the case of election studies, also framing studies would benefit from including field experiments as a part of the methodological repertoire.

\section{Deliberation}

Though the deliberative turn is a global trend (for example, Elster, 1999; Barabas, 2004), the deliberative focus is particularly scrutinised in a European context with its increased focus on democratic participation (for example, Papadopoulos and 
Election studies, news framing and deliberation are by no means the only EU sub-disciplines that have endorsed the experimental method. But they are highlighted here because they are some of the first sub-areas that permanently made experiments a part of their methodological toolbox. However, other fields and research questions have also been explored in EU studies. Below I briefly state some examples of topics, hoping to provide the reader with inspiration about the multiple purposes experiments can serve in EU research.

Bruter (2003) focuses on the impact of EU symbols in the news on the evolution of a civic and cultural EU identity. Applying a cross-country experiment, he finds EU symbols to play a significant role for the civic and cultural EU identity (Bruter, 2003). And, in more general terms, there tends to be a growing focus on the role of personal identity formation in I.R. theory (for example, Greenhill, 2008). Another recently explored area includes corruption. In Anduiza et al's (2013) experimental study on the role of partisanship on the view of comuption in Spain, they find that corruption is differently judged according to partisan membership. If the suspected politician belongs to the same party as the subject, corruption is perceived as less salient (Anduiza et al, 2013). Another research area includes a narrow exploration of the behavioural assumptions between the re-distributive and insurance-based understanding of welfare state organisation (Barber et al, 2013).

Finally what aspects are yet to be explored, while providing a good basis for a future research agenda using experiments? Again, many suggestions point in the direction of political psychology. This field increasingly call for attention to the importance of personality in politics (for example, Kuo and Margalit, 2012), just like some argue for focus on intergovermmental bargaining to psychological aspects of communication (for example, Grobe, 2010). A third aspect, receiving increased attention in the last years, is the focus on the role of the Internet on, for example, the political mobilisation or political awareness of people (for example, Margetts et al, 2011). Finally, returning to the four categories of experiments, we witness a growth in the use of lab and survey experiments, but less so with regard to field and natural experiments. Yet field and natural experiments are research designs that provide other insights than lab and survey experiments. Thus the less applied but nevertheless promising potentials of these designs should be explored further in future research.

\section{Experiments and Their Opposition: What is the Problem?}

The economist A. Roth states three purposes of experimental research. First, experiments search for facts; second, they speak to the theoretical world; and. finally, experimental research 'whispers in the ears of princes' (that is, make policy advices) (Roth cited in Druckman et al, 2011). Yet to achieve any of the goals above, one has to grasp more clearly the world of inference in which experiments exist.

Q 2014 Macmillan Publishers Ltd. 1472-4790 Comparattve European Polities 1-19 
consequently are psychologically engaged in the process (that is, psychological realism) as if it was real life, then the measured causal link and processes rank highly on mundane realism as well (that is, the overall design echoes real life). And, consequently, the measured treatment effect, if significant, can be understood to measure causal processes also taking place in real life. This way experiments not only enable us to ask questions hitherto problematic to investigate due to endogeneity concems; they also force us to re-think the way we normally validate our results.

\section{Conclusion}

Experiments are here to stay. And though we have come a long way from when the then-president of the APSA stated that politics is not an experimental science (Lowell, 1910), the use of experimental methods in EU research is still in its infancy. This article provided a state-of-the-art summary of the use of experiments in EU research as well as an exploration into which topics within EU research have been explored through experimentation in the last decades.

As shown, the experimental use in EU studies dramatically increased in the last decades. particularly survey and lab experiments. Although the use of experimentation in EU studies still lags behind more general political science figures, experimentation is indeed used more frequenuly in EU studies too. Additionally, the article provided an extensive account of three sub-fields of EU research where experiments have been used. These included the study of voter behaviour in EP elections or national EU referendums, the deliberative exploration in decision-making and the exploration of the role of news framing on EU attitudes. It remains nevertheless important to emphasise that more topics within EU studies have recently drawn on experimental methods.

Experiments are particularly good at exploring questions of causality. Based on the RCM counterfactual logic, they explore research questions that are normally hard to approach through conventional observational data, which often require complicated techniques to overcome endogeneity problems and causal identification. These questions are often derived from questions of political psychology, which cannot be measured properly through observational data. Where experiments are efficient tools to overcome these issues, they nevertheless require a somewhat different approach to validity and inference. Emphasising the aspects of mundane and experimental realism, I eventually argued for a new and broader approach to validity concerns.

\section{About the Author}

Julie Hassing Nielsen is assistant professor at the Department of Political Science, University of Copenhagen since 2013. She holds a PhD (2012) from the European University Institute in Florence. 
Exadaktylos, T. and Radaelli, C. (2009) Research design in European studies: The case of europeanization. Journal of Common Market Studies 47(3): 507-530.

Fishkin, J.S. and Luskin, R.C. (2005) Experimenting with a democratic ideal: Deliberative pooling and public opinion. Acta Politica 40(3): 284-298.

Foellesdal, A. and Hix, S. (2006) Why there is a democratic deficit in the EU: A response to majone and moravcsik. Journal of Common Market Studies 44(3): 533-562.

Franklin, M., Eijk, C.V.D. and Marsh, M. (1995) Referendum outcomes and trust in government: Public support for europe in the wake of maastricht. West European Politics 18(3): 101-117.

Gaines, B.J., Kuklinski, J.H. and Quirk, P.J. (2006) The logic of survey experiments reexamined. Political Analysis 15(1): 1-20.

Gerber, A.S. (2011) Field experiments in political science. In: J.N. Druckman, D.P. Green, J.H. Kuklinski and A. Lupia (eds.) Cambridge Handbook of Experimental Political Science. Cambridge, UK: Cambridge University Press.

Gerber, A.S. and Green, D.P. (2000) The effects of canvassing, telephone calls, and direct mail on voter tumout: A field experiment. American Polititical Science Review 94(3): 653-663.

Greenhill, B. (2008) Recognition and collective identity formation in international relations. European Jounal of International Relations 14(2): 343-368.

Grobe. C. (2010) The power of words: Argumentative persuasion in international negotiations. European Journal of International Relations 16(1): 5-29.

Grönlund, K., Setälä, M. and Herne, K. (2010) Deliberation and civic virtue: Lessons from a citizen deliberation experiment. European Political Science Review 2(1): 95-117.

Habermas. J. (2003) Toward a cosmopolitan Europe. Journal of Democracy 14(4): 86-100.

Haverland, M. (2006) Does the EU cause domestic developments? Improving selection in Europeanisation research. West European Politics 29(1): 134-146.

Hobolt, S.B. (2009) Europe in Question. Referendums on European Integration. Oxford, UK: Oxford University Press.

Hobolt, S.B. and Wittrock, J. (2011) The second-order election model revisited: An experimental test of vote choices in European parliament elections. Electoral Studies 30(1): 29-40.

Hooghe, L. and Marks, G. (2007) Sources of euroscepticism. Acta Politica 42: 119-127.

Hug, S. (2003) Endogenous preferences and delegation in the European union. Comparative Political Studies 36(2): 41-74.

Jupille, J. and Leblang, D. (2007) Voting for change: Calculation, community, and euro referendums. International Organization 61(4): 763-782.

Keltner, D. and Lemer, J.S. (2010) Emotions. In: S.T. Fiske, D.T. Gilbert and L. Lindzey (eds.) Handbook of Social Psychology. New York: John Wiley and Sons.

Kumlin, S. (2011) Claiming blame and giving credit? Unintended effects of how govemment and opposition frame the Europeanization of welfare. European Union Politics 12(4): 575-595.

Kuo, A. and Margalit, Y. (2012) Measuring individual identity: Experimental evidence. Comparative Politics 44(4): 459-479.

Lay, R.R. and Redlawsk, D.P. (2001) Advantages and disadvantatges of cognitive heuristics in political decision-making. American Political Science Review 45(4): 951-971.

Lecheler, S. and Vreese, C.H.D. (2010) Framing serbia: The effects of news framing on public support for EU enlargement. European Political Science Review 2(1): 73-93.

Lowell, A.L. (1910) The Physiology of Politics: Presidential Address, Sixth Annual Meeting of the American Political Science Association. The American Political Science Review 4(1): 1-15.

Lyengar, S. (2011) Laboratory experiments in political science. In: J.N. Druckman, D.P. Green, J.H. Kuklinski and A. Lupia (eds.) Cambridge Handbook of Experimental Political Science. Cambridge, UK: Cambridge University Press.

Maier, J. and Rittberger, B. (2008) Shifting Europe's boundaries: Mass media, public opinion and the enlargement of the EU. European Union Politics 9(2): 243-267. 
Vreese, C.H.D., Brug, W.V.D. and Hobolt, S.B. (2012) Turkey in the EU? How cultural and economic frames affect support for Turkish accession. Comparative European Politics 10(2): 218-235.

Vreese, C.H.D. and Kandyla, A. (2009) News framing and public support for a common foreign and security policy. Journal of Common Market Studies 47(3): 453-481.

Wilson, T.D., Aronson, E. and Carlsmith, K. (2010) The art of laboratory experimentation. In: D.T. Gilbert,

S.T. Fiske. and G. Lindzey (eds.) The Handbook of Social Psychology. Boston, MA: McGraw-Hill.

Zaller, J.R. (1992) The Nature and Origins of Mass Opinion. New York: Cambridge University Press. 